\title{
Christian Churches and National Integration in Cameroon since Reunification: A Historical Survey
}

\author{
Michael Kpughe Lang (PhD) \\ Higher Teacher Training College, Bambili, The University of Bamenda, Cameroon
}

\begin{abstract}
The reunification of Cameroon in 1961 heightened the need to forge a sense of national accommodation and common citizenship. The country's multi-ethnic make up and its disparate colonial heritages (British and French) pose insuperable impediments to viable nationhood. Worse still, the country's unity is marred by religious cleavages and differences (Muslim north vs. southern Christian; Muslim vs. animist; Christian vs. animist, etc.). Indeed, religious cleavages and differences were threats to the integrative process of the country. These differences were also reflected in the parochial and regional character of Christian churches (Catholics and Protestants) resulting from the ecclesiastical colonial mould. Thus, there was need for practical and effective methods aimed at bridging denominational gaps and differences in view of fostering national unity. This paper examines the contributions of Catholic and Protestant churches to the process of national integration in Cameroon from different perspectives: institutional-structural, ecumenical, and evangelical. It sustains the argument that churches did not only foster national unity, but were equally affected by it. The paper concludes that the churches' structures, ecumenical bodies and evangelical initiatives, in spite some pitfalls, transcend the multi-ethnic differences and the dual colonial heritages, coinciding with the boundaries of the nation state.
\end{abstract}

Keywords: Christian churches, integration, ecumenism, Catholics, Protestants and Cameroon

\section{INTRODUCTION}

One of the most fundamental problems African states faced during the immediate post-independent era was national integration. The multi-ethnic make-up of most African countries posed obstacles to nationhood. ${ }^{1}$ For example, Nigeria contains three major disparate ethnic groups: Yoruba, Ibo and Hausa-Fulani. Some states have more than 200 diverse ethnic groups whose languages, cultures, social and political institutions, and values significantly differ. This multi-ethnic nature of African states emanated from colonial rule. According to Kah and Nkwi, the demarcation of artificial boundaries by colonial powers fractured historically homogenous ethnic groups. ${ }^{2}$ But it should be added that colonial boundaries created states hosting multitudes of disparate ethnic groups. These national frontiers drawn up by colonial masters rarely matched ethnic borders. Thus, colonial boundaries rendered the task of forging a sense of national unity within African states very difficult.

Since the attainment of political independence by most African countries in the 1960s, the concern of African leaders has been to formulate policies in an effort to consolidate the multitude of diverse and often discordant ethnic groups within their borders into stable national communities. ${ }^{3}$ Indeed, the need to instill a sense of national identity within newly independent African states was underlined. The fear

1. For more on that issue, see Dudley, B. J., "Military Government and National Integration in Nigeria" in Smock, David and Bentsi-Enchill, K., eds., The Search for National Integration in Africa, New York, The Free Press, 1972, pp. 117-139; Southall, A., "The Current State of National Integration in Uganda" in Smock, David and Bentsi-Enchill, K., eds., The Search for National Integration in Africa, New York, The Free Press, 1972, pp. 307-333.

2. H. K. Kah and W. G. Nkwi, "Colonial Boundaries and Disintegration: A Study of the Boki 'Nation' of the Cross River Region of Cameroon and Nigeria", in Daniel Awa, Albert-Pascal Temgoua et al., eds. Boundaries and History in Africa: Issues in Conventional Boundaries and Ideological Frontiers, Bamenda, Maryland Publishers, 2011, pp. 45-46.

3. For instance, see David Smock and K. Bentsi-Enchill, eds., The Search for National Integration in Africa, New York, The Free Press, 1972, pp. 1-4. 
was that African countries could break up into even smaller units if adequate steps were not taken to foster a feeling of nationhood. ${ }^{4}$

In Cameroon, the situation was worse given that impediments to national integration did not only come from her multi-ethnic make up, but from her widely disparate colonial heritages (British and French). ${ }^{5}$ As a matter of fact, the population of Cameroon is a blend of more than 200 different ethnic entities, whose languages, cultures, social and political institutions, and customs differ significantly. ${ }^{6}$ Besides, there were widely differing political, social, administrative, religious and cultural traditions between Anglophone and Francophone Cameroon resulting from the territories' multiple colonial encounter with the British and the French. For LeVine, Cameroon's colonial past contributed to its fragmentation. ${ }^{7}$ Initially annexed and governed by Germany (between 1884 and 1916), the territory was eventually partitioned and placed under Britain and France first as mandates of the League of Nations and later as trust territories of the United Nations. In October 1961, the southern portion of British Cameroon reunified with French Cameroon to constitute Africa's pioneer bilingual federation. ${ }^{8}$ The young state encompassed people who were not only separated by ethnic disparities, but by marked contrasts in language, law, administration, education, economic development, and political style emanating from the separate colonial experiences.

Apart from the above disparities, the new state inherited a multitude of Christian churches from colonial missionary bodies. ${ }^{9}$ In fact, Protestant missionary societies granted autonomy to churches whose activities were limited in the Anglophone or Francophone zones of the country. The activities of churches that resulted from the ecclesiastical colonial mould failed to correspond with the boundaries of the national state. Denominational boundaries often followed regional and ethnic frontiers. This was a legacy of the territorial policies of the nineteenth and twentieth century mission boards. For example, the Presbyterian Church in Cameroon which gained autonomy from the Basel Mission in 1957 limited its activities only in West Cameroon. ${ }^{10}$ Similarly, the Cameroon Baptist Convention which was established in 1954 centered its evangelical activities only in West Cameroon. On the other hand, newly created churches in the former French Cameroon like the Presbyterian Church of Cameroon and the Evangelical Church of Cameroon limited their activities in East Cameroon. In addition, there existed Catholic churches in the Anglophone and Francophone portions of Cameroon that were in no way connected. ${ }^{11}$

It is therefore evident that the differences among Cameroonians were also reflected in the parochial and regional character of Protestant and Catholic churches. The Christian population was and is still

4. Ibid.

5. For a discussion of ethnic and colonially inherited disparities in Cameroon, see Fonlon, B., "The Language Problem in Cameroon: An Historical Perspective" in Smock, David and Bentsi-Enchill, K., eds., The Search for National Integration in Africa, New York, The Free Press, 1972, pp. 189-206; LeVine, V. T., "Political Integration and the United Republic of Cameroon" in Smock, David and Bentsi-Enchill, K., eds., The Search for National Integration in Africa, New York, The Free Press, 1972, pp. 270-285; Monga, Y., « «Au village!»», Cahiers d'études africaines [Online], $160 \mid 2000$, Accessed on 5 May 2012. URL: http://etudesafricaines.revues.org/46

6. See for example, J. Willard, The Cameron Federation. Political Integration in a Fragmentary Society, Princeton, Princeton University Press, 1970.

7. LeVine, "Political Integration", p. 273.

8. For insightful treatment of the colonial history of Cameroon, read V. G. Fanso, Cameroon History for Secondary Schools and Colleges, Vol. 2, The Colonial and Post Colonial Periods, London, Macmillan, 1989; V. G. Ngoh, History of Cameroon Since 1800, Limbe, Presbook, 1996. The northern portion of British Cameroon was officially attached to Nigerian following the results of the February 1961 plebiscite.

9. See E. Mveng, Histoire des Eglises Chrétiennes au Cameroun : Les Origines, Yaoundé, Imprimerie Saint Paul, 1990; A. Ndi, Mill Hill Missionaries in Southern West Cameroon 1922-1972: Prime Partners in Nation Building, Nairobi, Paulines Publications Africa, 2005; M. B. Funteh, "A Historical Survey of the Strategy for Church Expansion in Cameroon: The Case of the Mainstream Denominations" in Kaliao, Volume 1, No. 2, December 2009, pp. 49-68.

10. See particularly, K. Werner, The History of the Presbyterian Church in West Cameroon, Victoria, Presbook, 1969.

11. For more information on the limitation of churches' activities to specific areas of Cameroon, see D. H. Chimi, «Les Organes de Promotion de l'unité des Protestants au Cameroun 1941-2005 », Mémoire de Maitrise en Histoire, Université de Yaoundé 1, 2007; O. Etuge, "Church Union in Cameroon", Bachelor Dissertation in Theology, Theological College Nyasoso, 1977, pp. 32-45. 
divided between Catholics (38.4 percent of the total population), Protestants (26.3 percent), and other Christian denominations (4 percent). ${ }^{12}$ The two Anglophone regions of the western part of the country are largely Protestant, and the Francophone regions of the southern and western areas are mostly Catholic. In the northern region, the dominant Fulani ethnic group is mainly Muslim, but the overall population is fairly evenly distributed among Muslims, Christians, and followers of indigenous religions. Thus, there was need for practical and effective methods aimed at bridging denominational gaps and differences in view of fostering national unity. Since the reunification of Cameroon, the mainstream Christian churches have enabled their names, institutions, structures and ecumenical, evangelical and social activities to coincide with the boundaries of the national state. Indeed, mainline churches assumed a more decisive role as a factor promoting attachment to the larger national unit beyond the ethnic group, beyond individual churches and beyond each of the colonial heritages. The churches, I believe, seemed to provide hope for national cohesion based on cross-cutting affiliations. This paper examines the contributions of the Catholic and the Protestant churches to the process of national integration in Cameroon along several dimensions: institutional-structural, ecumenical, and evangelical. It sustains the argument that churches did not only foster national unity, but were equally affected by it.

\section{INSTITUTIONAL-STRUCTURAL INTEGRATION}

The institutions and structures fashioned by mainstream churches had the potential of enhancing national integration in Cameroon shortly after independence and reunification. During the immediate post-independence era, the various Protestant and Catholic churches in Cameroon carried out institutional and structural reforms dictated largely by the reunification between French and British Cameroons and the consideration of national unity by the Ahidjo government as a dire necessity. Indeed, the churches were committed towards transforming their institutions and structures in an effort to enable them reflect the boundaries of reunified Cameroon. As earlier pointed out, the names, institutions and administrative structures of these churches did not coincide with the boundaries of Cameroon. Rather, they coincided with the frontiers of either West Cameroon or East Cameroon.

A glaring example is the PCC whose initial name at independence was Presbyterian Church in the Cameroons. ${ }^{13}$ But the name and structures of the church did not reflect the boundaries and federal character of the country, especially following the 1961 reunification. Consequently, authorities of the church took measures to effect constitutional reforms in view of accompanying the political evolution of the country. In May 1963 when the constitution of the Presbyterian Church was amended, the name of the Church was changed from the Presbyterian Church in the Cameroons to the Presbyterian Church in West Cameroon (PCWC). ${ }^{14}$ Although the name reflected only the state of West Cameroon, it evidenced the desire of the church's leadership to give the church a national character. Considering that the PCWC comprised local churches inherited from the Basel Mission, there was need to put in place structures capable of firmly knitting these churches together. The structures of the church were hierarchical and included the General Synod, the District Synod, the Presbyterial Synod and the Session of the Congregation. This enabled the Presbyterian Christians to be represented at all levels of the church's administration. Indeed, all Christians and aspects of the church throughout West Cameroon became firmly placed under the General Synod. In order to further forge a sense of unity among its Christians, the General Synod decided in 1968 to abolish the two districts (Grassfields and Forest). ${ }^{15}$ The two districts distinguished between grassfields and forest region Christians in northwest and southwest respectively. This was no longer going to be the case since the 1968 amendment ended the division by administratively dividing the church into presbyteries and congregations.

Following the unification creating the United Republic of Cameroon in 1972, the General Synod of PCWC decided on 6 June 1973 to rename the Church as Presbyterian Church in Cameroon (PCC). ${ }^{16}$

12. See Cameroon, http://www.state.gov/documents/organization/171604.pdf. Accessed on 10 May 2012. This implies that Christians constitute about 69 percent of Cameroon's population (about 20.4 million).

13. Werner, The History of the Presbyterian Church, p. 82; M. K. Lang, "The Menchum-Boyo PresbyteryGoppingen Deanery Partnership 1968-2008: A Historical Investigation” Ph.D Thesis in History, University of Yaounde 1, 2012, p. 63.

14. Ibid.

15. J. N. Dah, "The Vision and Challenges of an Autonomous Church", in Dah J. N., (ed.), Presbyterian Church in Cameroon: 50 Years of Selfhood, Limbe, Presprint, 2007, p. 42.

16. Lang, "The Menchum-Boyo Presbytery", p. 63. 
This was not only caused by the dismantling of the federal system which resulted in the disappearance of the state of West Cameroon, but by the church's desire to be part and parcel of the process of national integration in Cameroon. The significance of this change of name with regard to national integration was that the appellation of the church now reflected the name and boundaries of Cameroon. In the course of time following the church's expansion into Francophone Cameroon, her structures were made to coincide with the boundaries of the national state, transcending the division between Anglophones and Francophones. Thus, the national character of PCC's structures helped in fading away disparities emanating from the country's dual colonial heritages.

Similarly, the names and structures of churches in Francophone Cameroon were made to reflect the boundaries and national character of Cameroon. At the end of its missionary mission in Cameroon, the American Presbyterian Mission (APM) granted autonomy to the indigenous Christians in 1957. In 1961 following the reunification of Cameroon, the Presbyterians of the English and French-speaking regions of Cameroon united to form Presbyterian Church of Cameroon. The national character of this church was reflected in its name and structures. Also, the local Baptist Christians of the Frenchspeaking part of Cameroon got independence as Union of Baptist Churches in Cameroun (UBCC). ${ }^{17}$ In the English-speaking part of Cameroon, the local Baptist Christians gained independence from the Cameroon Baptist Mission on 15 December 1954 as Cameroon Baptist Convention (CBC). ${ }^{18}$ All the above churches possessed names and structures that cut across the ethnic and colonial cleavages of the country.

Of particular note was the structure and reorganization of the CBC. When the indigenous Baptist churches in English-speaking Cameroon gained independence in 1954 as CBC, all the local churches, associations and fields were attached to the latter's highest governing body (the Convention). The way local congregations, associations and fields were attached to the Convention transcended the ethnic disparities among Baptist Christians. Funteh described the structure of the $\mathrm{CBC}$ and its potential of forging cohesion among the multi-ethnic Baptist Christians in English-speaking Cameroon in these words:

The $\mathrm{CBC}$ was hierarchically structured (ascending) from the local congregation through the association and field to the Convention. The church, the local congregation, made up the smallest unit of the Convention. A group of churches made up the association, while a number of associations grouped together made up a field, and then the Convention, which encompassed all the fields. ${ }^{19}$

Thus, the CBC achieved almost complete Baptist Christian integration in English-speaking Cameroon irrespective of their ethnic origins. In fact, the ascending administrative units of the church generally cut across Northwest and Southwest, linguistic and cultural boundaries.

The expansion of the CBC since 1961 especially into French-speaking Cameroon necessitated its restructuring in view of encompassing the new Christians and local churches. This was partly due to the desire for political unity that followed independence and reunification of the French and British sections of Cameroon in 1961. This wave of activity to promote national integration by the Government of Cameroon at this time, according to Funteh, infected all aspects of Cameroon life, including the Church. During this time, the need for Christian unity in the churches dominated the speeches of local church leaders. ${ }^{20}$ This among other things dictated the reorganization of the CBC which was marked by the creation of regions. All the fields were grouped into three regions each administered by regional presidents whose main duty was to unify Baptist Christians at the regional level. Besides, the CBM was officially fused into CBC in the late 1970s probably prompted by the establishment of a unitary system in Cameroon in 1972. It is worth pointing out that the integration of the $\mathrm{CBC}$ and $\mathrm{CBM}$ enhanced political unity in Cameroon. ${ }^{21} \mathrm{New}$ central structures like the General

17. For a discussion of the transformation of churches' structures in the French-speaking region of Cameroon, see Chimi, "Les Organes de Promotion de l'unité".

18. Funteh, "A Historical Survey of the Strategy for Church Expansion”, p. 59.

19. M. B. Funteh, "Intra-Cameroon Baptist Convention Conflicts 1954-2002: A Historical Investigation", Unpublished Ph.D. Thesis in History, University of Yaounde I, 2008, p. 97.

20. Ibid., p. 110.

21. The CBM, it should be noted, granted independence to the CBC in 1954 and continued its activities as a missionary body. Following the unification of Cameroon in 1972, the CBM was fused into the CBC. The negotiations which preceded the integration arguably emanated from the church's desire to enhance Christian and national unity in Cameroon. 
Session which encompassed all other organs and structures undoubtedly promoted Christian unity in the CBC. On the whole, the $\mathrm{CBC}$ was an amalgamation of the Grassfields and Forest Christians, people of two distinct cultural backgrounds and heritages. ${ }^{22}$ The structuring of the CBC, in spite of internal conflicts, enabled it to stand beyond the sharp ethnic differences that characterized her Christians.

Apart from Protestant churches, the Catholic Church also demonstrated its attachment to national integration and national unity by example and witness. The Church saw the unity of Catholic Christians as a dire necessity. As earlier stressed, the Catholic churches in English and Frenchspeaking regions of Cameroon resulted from distinctive colonial missionary societies. Worse still, Catholic Christians in each of these regions were divided by injurious ethnic disparities. It was therefore necessary to strengthen the unity of all Catholic Christians first in the two colonially inherited regions and later in the entire reunified Cameroon. During the immediate post reunification era, a lot was done in East and West Cameroon to knit Catholic Christians together. Small Catholic Christian communities, mission stations, parishes, zones and dioceses were bound to the central Catholic Church forever. ${ }^{23}$ This hierarchical structure undeniably forged a cohesive national Catholic Christian community from a multitude of ethnic groups as well as from the disparate colonial heritages. For Anthony Ndi, the creation of outstations, parishes, dioceses, ecclesiastical provinces, seminaries and lay Catholic establishments cut across East and West, Anglophone and Francophone, linguistic and cultural frontiers. ${ }^{24}$ As shall be argued later in this paper, the Roman Catholic Church transcended the boundary between English-speaking and French-speaking portions of Cameroon to be transformed into a national church due to ecumenical networking.

To sum up, the various Roman Catholic and Protestant churches in Cameroon modified their names and structures in an effort to bridge ethnic and colonial differences that characterized their Christians. Thus as Cameroon's institutions and structures were mutating for the benefit of national unity, Christian churches also transformed their structures in view of forging national Christian cohesion. But apart from structural integrative measures, these churches employed ecumenical networking strategies as a means of promoting the unity of Christians in churches and in Cameroon as a whole.

\section{ECUMENICAL NETWORKING}

The history of Christianity is dominated by ecumenism whose history dates to the New Testament church itself. ${ }^{25}$ Indeed efforts have always been made to foster unity among Christians. The bases of Christian unity are spelled out in the Holy Bible. For instance, Christ says in John 17:20-23 that "I do not pray for these only, but also for those who believe in me through their word, that they may all be one..." Thus Christian unity is something inevitable because it is the result of being born into a given family. Christians are brothers and not merely an association of friends. So, the Protestant and Catholic Christians in Cameroon listened to this exhortation which urges them to maintain with diligence the unity into which they have been brought. They sought to pursue Christian unity at a time when the Government of Cameroon was trying to fade away the numerous differences among Cameroonians. The enhancing of Christian unity is an indispensable tool that can be used to promote national integration in Cameroon. This is because, over the years, the number of Christians steadily increased. During the immediate post-reunification era, the Christian population of the country stood as follows; PCWC 63,000, Evangelical Church of Cameroon 83,000, Presbyterian Church of Cameroon 92,000, Baptists 50,000 and about 2,000,000 Catholics. Today, according to Funteh, the identification of the population with the various mainstream denominations stands as follows Catholics 6,300,000, Baptists 198,000 and 1,300,000 Presbyterians. ${ }^{26}$

Following the reunification of Cameroon, mainline churches embraced ecumenism capable of contributing to national integration. There was intra and inter church ecumenism intended to bridge

22.Ibid., p.125.

23.Ibid., p. 95.

24. Ndi, Mill Hill Missionaries, p. 319.

25. For more information on the ecumenical movement, read Barot, M., Le Mouvement Oecuménique, Paris, Presses Universitaire de France, 1967; Birmele, A., (ed.), Local Ecumenism: How Church Unity is Seen and Practiced by Local Congregations, Strasbourg, Institute for Ecumenical Research, 1984; Cavert, S. M., On the Road to Christian Unity: An Appraisal of the Ecumenical Movement, New York, Harpers and Brothers Publishers, 1961.

26. Funteh, "A Historical Survey of the Strategy for Church Expansion”, p. 67. 
the gaps between French-speaking and English-speaking Christians as well as those between Catholics and Protestants. ${ }^{27}$ It is therefore argued in this section that the establishment of ecumenical ties between some mainline churches in Cameroon was an exciting sphere of bonding between the Christians and people of the Northwest and Southwest regions and throughout the national territory. Ecumenism in Cameroon took various dimensions and forms: the attempted church union and the creation of Protestant and Catholic ecumenical blocs (Federation of Evangelical Churches and Missions in Cameroon, the Council of Protestant Churches in Cameroon and the National Episcopal Conference of Cameroon).

\subsection{The Attempted Church Union}

After the reunification of Cameroon, mainline Churches, especially Protestants saw the need to form a single united church capable of breaking the barriers between French-speaking and English-speaking regions of Cameroon. In the words of the then Moderator of the PCC, Rev. Abraham Ngole: "All Christian churches in Cameroon should follow the footsteps of their government by forming a corporate organic body". ${ }^{28}$ Attempts to create a Church Union in Cameroon were started by the PCC when she left the Christian Council of Nigeria in $1963 .^{29}$ This was dictated by the reunification of Cameroon in 1961. During her 1964 General Synod, the PCC sent out invitations to other churches within the Federal Republic of Cameroon to study the issue of church union. The positive responses from the ECC and the Presbyterian Church of Cameroon led to the formation of the Church Union Committee of Cameroon (CUCC) on 11 November $1964 .{ }^{30}$ From the beginning, the CUCC comprised two churches from the French-speaking region of Cameroon (ECC and Presbyterian Church of Cameroon) and one from English-speaking Cameroon (PCC). The task of the CUCC was to explore ways and means of creating a United Church. It therefore had to sensitize other churches and to prepare a constitution for the would-be United Church.

The CUCC communicated the issue of the United Church and constitutional proposals not only to their Christians but also to leaders of other mainline churches. Besides, pastors of churches that make up the CUCC began meeting in joint retreats to study the word of God and to get to know each other in worship and fellowship. One of such retreats took place in Douala in September $1966{ }^{31}$ The activities of the committee attracted other churches. In April 1967, the African Protestant Church and the UBCC became full members of the CUCC. These five negotiating churches began working towards opening a Joint Theological College in Douala as a means of enhancing unification. According to the Secretary of the CUCC, Rev. Hermann Herzog, it was relevant to establish such a united college because those who receive the same training can overcome the disparities and suspicion that separate churches. ${ }^{32}$

With the foregoing preparations, the five negotiating churches accepted to meet on 12 September 1967 to officially proclaim the Church Union. On that day, the representatives of the churches created the Church Union. But the decision was to be presented to their synods for approval. During the meeting, the 23 persons representing the various churches issued a declaration which stated, inter alia, that "We believe that the unity to which God is leading us will make the church in Cameroon a more effective instrument for the accomplishment of His will and nation building. ${ }^{33, "}$ In 1967 therefore, expectations were high that five mainline churches in Cameroon will unite into a single Church Union. Unfortunately, the leaders of these churches failed to agree on several issues relating to the discipline of the United Church. In spite the repeated visits by the CUCC's Secretary to the various churches and the institutionalization of Church Union Sundays marked by a common liturgy, the whole project of creating a United Church in Cameroon was a fiasco. According to Ngwa, all visible signs toward developing this project lost image. ${ }^{34}$ In spite of this failure, the attempt to create a United

27. Etuge, "Church Union”, p. 47.

28. Ibid.

29. Lang, "The Menchum-Boyo Presbytery", pp. 63-64. The PCC severed links with the Christian Council of Nigeria because of the reunification of Southern Cameroons with the Republic of Cameroon.

30. Etuge, "Church Union", p. 47; H. A. Ngwa, "Ecumenism in Cameroon: A Survey of Some Ecumenical Developments from the 1960s to 1991", Bachelor Dissertation in Theology, Presbyterian Theological College Kumba, 1991, p. 21.

31. Ibid.

32. Ibid., p. 22.

33. Etuge, "Church Union", p. 48.

34. Ngwa, "Ecumenism in Cameroon", p. 22. 
Church enhanced national integration by placing mainline churches on the path to ecumenical relations. At least, churches were made to understand the need for Christian unity in a multi-ethnic country like Cameroon plagued by disparate colonial heritages.

\subsection{The Role of Intra-Protestant Ecumenical Groups}

Although Christian churches did not succeed to knit themselves together in a United Church, they pursued unity through Protestant ecumenical bodies, namely, the Federation of Evangelical Churches and Missions in Cameroon better known by its French acronym, FEMEC and the Council of Protestant Churches in Cameroon (CPCC). The former grew out of the Evangelical Federation of Equatorial Africa which was established in 1943 with Yaoundé as its headquarters. Following the granting of independence to Equatorial African territories and their eventual withdrawal from the federation, Protestant Churches in Cameroon formed an ecumenical body in 1969 known as FEMEC..$^{35}$ This ecumenical body brought together churches from Anglophone Cameroon (PCC and $\mathrm{CBC}$ ) and churches from Francophone Cameroon like the ECC, Presbyterian Church of Cameroon, UBCC, African Protestant Church, Lutheran Fraternal Church, etc.). ${ }^{36}$ The main goal of FEMEC was to bridge church boundaries and foster peaceful coexistence among Protestant Christians in Cameroon. The organization, according to Ngwa, welcomed churches and missionary bodies recognized by the Government of Cameroon. It laid emphasis on ecumenical developments, ensuring that its activities coincided with the boundaries of the national state. ${ }^{37}$

The structures of FEMEC reflected the boundaries and unity of Cameroon. It had an organic set up, comprising the Council, the Committee and the Executive Committee. Each organ was comprised of delegates from each of the member churches or missions. ${ }^{38}$ The numerous achievements recorded by FEMEC since its birth in 1969 arguably testifies the reality of ecumenism and Christian unity in Cameroon. In fact, the numerous cleavages that characterized Protestant Christians during the immediate post-independence era in both French and English-speaking regions of Cameroon have largely been eroded. All the activities of FEMEC resulted from joint planning involving member churches. Thus, FEMEC promoted Christian unity by retaining the traditions, identities and peculiarities of respective denominations. The organization tried in its own way to follow the footsteps of the Cameroon Government in fostering national integration. For Chimi, Protestant churches were motivated by government policy towards national unity to enhance unity among their Christians. ${ }^{39}$ On the ecumenical level, FEMEC was virtually identical with the state. Amazingly, some doubts still persist within Protestant churches and individual Christians as to whether FEMEC's ecumenical mission was ever firmly realized. It is not therefore inappropriate to observe that FEMEC, despite its national character, failed to bring together all churches and missions in Cameroon. As a matter of fact, some churches and missions refused to join the organization. Thus, the organization failed to become a veritable Christian associational catalyst of national integration. In 2005, FEMEC was transformed into CPCC. ${ }^{40}$

Mainline Protestant churches also used the CPCC as a tool with which to foster Christian unity in Cameroon. Established in 2005, the CPCC was to encompass a reasonable number of Protestant denominations in Cameroon. The purpose of this ecumenical body is not only to urge Protestant churches understand their own calling as God's partners in mission, but to promote unity among Protestant Christians. In 2006, the CPCC developed a pilot project in collaboration with the World Alliance of Reformed Churches aimed at bringing Christians of CPCC member churches together in action and reflection. ${ }^{41}$ Since 2007 , there has been a measure of ecumenical cooperation on the national level. In May 2007, an intercultural workshop with ecumenical facilitators from different regions in Cameroon took place in Yaoundé, resulting in a plan of action for ecumenical mission action-reflection in four local settings in Cameroon (Yaounde, Bertoua, Garoua and Buea). The workshop, according to its coordinator, Jean-Emile Ngue, culminated in CPCC's annual "Protestant

35. Chimi, "Les Organes de Promotion de l'unité", p. 33.

36. See Ngwa, "Ecumenism in Cameroon", p. 22.

37. Ibid.

38. Chimi, "Les Organes de Promotion de l'unité", p. 38.

39. Ibid., p. 110.

40. Amougou, A. G., «Le Conseil des Eglises Protestantes de Yaoundé (CEPY): De 1954 a 2004. Essai

D’Analyse Historique », Mémoire de Master en Histoire, Université de Yaoundé 1, 2012, p. 107.

41. "Mission Today", www.warc.ch/mission/Edinburgh 2010/WARC studies, Accessed on 6 May 2012. 
Week" under the theme "Unite together in mission". ${ }^{42}$ The ecumenical activities of the CPCC testify how it contributed in bridging denominational cleavages resulting from the territorial policies of mission bodies.

\subsection{Intra-Catholic Ecumenical Networking}

At the time of Cameroon's independence and reunification, Catholic churches resulting from varying missionary bodies were not united. As earlier pointed out, Catholic Christians in English-speaking Cameroon had little or no connection with those in French-speaking Cameroon. Whatever, the Catholic denomination had the potential to offer greater hope for national unity based on cross-cutting affiliations. The leaders of the church exploited the mechanisms available to them to fade away ethnic, religious and colonially inherited disparities in the reunified Cameroon. As the experience of other states such as India and Uganda ${ }^{43}$ demonstrates, the involvement of the Catholic Church in the development of a national community from heterogeneous ethnic groups can be facilitated through ecumenical relations.

Since the reunification of Cameroon in 1961, the Catholic Church has promoted national cohesion through ecumenical networking. It all began in 1961 in the former West Cameroon when the Buea Diocese detached from the Metropolitan See of Onitsha. ${ }^{44}$ This move was dictated by the reunification of Cameroon since it heightened the need for greater cooperation between Catholic churches in West and East Cameroon. In order to demonstrate their commitment to incubate national loyalty and cohesion in Cameroon, the Catholic Church in West Cameroon was attached to the Yaoundé Metropolitan See in East Cameroon. This attachment emanated from the ecumenical negotiations involving Bishop Jules Peeters of Buea Diocese (the lone diocese in English-speaking Cameroon at the time) and Mgr. Jean Zoa, Archbishop of Yaoundé. ${ }^{45}$ This merging of Catholic Anglophones with Francophone Catholics was one of the many steps required to enhance national integration in Cameroon. Although it was traumatic for Anglophones as they were already acquainted working with their Nigerian counterparts, they understood with time that the move had the potential to aid the national integration project in Cameroon.

In 1970, the Diocese of Buea was split and the Bamenda Diocese was created. Two bishops, Paul Verdzekov and Pius Awa, were ordained and placed at the helm of the Bamenda and Buea Dioceses respectively. The presence of the Archbishop of Yaoundé, Mgr. Jean Zoa in the consecration ceremony set new national integration trends. ${ }^{46}$ It was a sign of cooperation between the Catholic Church in East and West Cameroon. Besides, it was a pointer to greater cooperation in the future among Catholic Christians in Cameroon. Indeed, the merging was swiftly followed by negotiations in view of establishing a Roman Catholic ecumenical body in Cameroon. During these negotiations, Anglophone Catholics were led by Bishops Verdzekov and Awa while Francophone Catholics were led by Mgr. Zoa. The immediate outcome of this intra-Catholic ecumenical networking was the creation of the National Episcopal Conference of Cameroon (NECC) in the early 1970s. ${ }^{47}$ The NECC is headed by a President who presides over the life of the Catholic Church in Cameroon. The conference holds every year with all the dioceses represented by their bishops. Anthony Ndi who sees the NECC as a catalyst for national integration in Cameroon notes that the body has a Permanent Secretariat with Executive Sub-Episcopal Commissions that cater for services such as education, health, justice and peace and social welfare. ${ }^{48}$ This has enabled the NECC to stand above the numerous disparities in Cameroon by addressing issues affecting the lives of Cameroonians.

The fear among English-speaking Cameroonians of being dominated by Francophone Catholics was quickly eroded when Anglophone Bishops were elected to preside over the NECC. In fact, three

42. Ibid.

43. See Aparna Sundar, "Thinking beyond Secularism: The Catholic Church and Political Practice in Rural South India", South Asia Multidisciplinary Academic Journal [Online], Free-Standing Articles, Online since 19 April 2012, connection on 05 May 2012. URL : http://samaj.revues.org/3368 ; Southall, A., "The Current State of National Integration", pp. 307-333.

44.E. F. Sanosi, "The Catholic Church - architect of national integration in Cameroon" L'Effort Camerounais, No. 503, June 2010.

45. Ibid.

46. Ibid.

47. Ibid.

48. Ndi, Mill Hill Missionaries, p. 317. 
English-speaking bishops served at different times as Presidents of NECC. They include Bishops Paul Verdzekov, Christian Tumi and Cornelius Esua. The NECC, as Sanosi points out, has achieved almost complete Catholic integration in Cameroon. For him, it is thanks to the Catholic Church that the Cameroon Government has made giant national integration strides.

\subsection{Bridging Gaps Between Catholics and Protestants}

The mainstream Christian churches in Cameroon have since reunification been involved in ecumenical networking that can be of benefit to the Cameroon Government in the search for national cohesion. Since the 1960s, ecumenical dialogue intended to foster Christian unity in Cameroon (Catholics and Protestants) has been under taken. Mainline churches understood what role Christian unity could play in the mass mobilization and preservation of national unity. This explains why ecumenical bodies bringing Catholics and Protestants together were established. For the authorities of these churches, a policy of integrating Christians into Cameroonian national life through joint ecumenical blocs was feasible. They saw the creation of national and regional ecumenical blocs as a basis for knitting Christians from diverse confessions and backgrounds together.

In Cameroon today, there exist small joint ecumenical groups all over the national territory. These blocs are centres were Christian solidarity between Catholics and Protestants is enhanced. Their ecumenical activities which are manifested in different ways and forms go beyond denominational, ethnic and colonial cleavages in Cameroon. Of particular note is the Joint Action Group (JAG) that was created in 1973 by Reverend Father Karlham (a Catholic Priest) and Rev. Hermann (a Presbyterian). ${ }^{49}$ Since its birth, the JAG has promoted ecumenical dialogue between Catholics and Protestants in Meme Division. This group which consists of the Presbyterian, Baptist, Catholic, Lutheran and Anglican denominations undertakes her ecumenical ventures largely for the sake of promoting Christian unity in Cameroon. Through its multiple activities, the JAG has enabled Christians from diverse denominations to collaborate at various levels: preaching, singing and worship. Through this joint action, practical collaboration between churches in the Kumba area has been expanded and deepened. ${ }^{50}$ As a result, the attitude of either neglecting or marginalizing some Christians and churches has largely faded away. There exist many other Catholic-Protestant ecumenical bodies with the potential of enhancing national cohesion in Cameroon. This ranks ecumenical groups (comprising Protestants and Catholics) among the many steps required to promote national integration in Cameroon.

Besides, mainline churches in Cameroon ensure harmonious unity in diversity through the celebration of important events such as the consecration of bishops, ordination of priests and pastors, and celebration of jubilees. These events, according to Ndi, are rallying occasions for the manifestation of the unity among Catholic and Protestant Christians in Cameroon. Ndi particularly contends that "these celebrations simply through continuous cultural interchange in terms of music, lyrics, instruments and style are in the course of fusion into a unique Cameroonian liturgy ready for export." ${ }^{\text {51 }}$

\section{EvangeliSM AND NATIONAL UNITY}

The mainstream churches, since reunification, have been involved in various forms of evangelization across the national territory. Although intended to offer each of the churches a firm ecclesiastical base, evangelical activities have assisted the state in nationalizing the Christian community and supporting the drive toward national integration. I argue in this section that, due to the numerous strategies of evangelization (creation of new congregations, presbyteries, fields, parishes, dioceses, Christian associations, etc.), the mainline churches have aided the process of national unity in Cameroon.

Operating under the influence of competition and outweighing each other in the race for souls, mainline denominations adopted several methods of evangelism. Some of these strategies, as earlier noted, had the potential of enhancing national cohesion. The PCC apart from carrying her activities into all nooks and crannies of the English-speaking region of Cameroon equally expanded into the French-speaking region. According to Rev. Dah, the PCC has been involved in the extension of the Church by way of winning new converts and planting new congregations in virgin areas across the

49. See Ngwa, "Ecumenism in Cameroon", p. 28.

50. Ibid., p. 30.

51. Ndi, Mill Hill Missionaries, p. 320. 
national territory. ${ }^{52}$ For Ejedepang-Koge, PCC's expansion into the Francophone area since 1973 emanated from the establishment of the unitary state following the peaceful revolution of May 1972. ${ }^{53}$ Today, there exist numerous Presbyterian congregations in Francophone Cameroon which are divided into three presbyteries (East Mungo North, East Mungo South and Grand North). Similarly, the CBC after planting itself well in the Anglophone region, expanded into the French-speaking region. Her presence in the latter region, since 1978, is evidenced by the presence of her fields, namely, Bafoussam, Yaoundé, Ngoundere, Maroua, Garoua, Douala and Nkongsamba. ${ }^{54}$ But most PCC and $\mathrm{CBC}$ churches in the Francophone region are dominated by English-speaking Christians who moved and settled in this area.

Other mainline churches, especially those whose activities were limited to the Francophone zone equally began expanding into the Anglophone region. For instance, the ECC and the Presbyterian Church of Cameroon now operate congregations in the northwest and southwest regions of Cameroon. Even the Catholic Church has enabled her evangelical activities to coincide with the boundaries of the national state. More dioceses have been opened in various parts of English and French-speaking Cameroon. Generally, the lethargy that confined mainline churches either in Anglophone or Francophone Cameroon has been broken through cross country evangelism. This, in my opinion, has helped in dismantling colonially inherited cleavages. Presently, mainstream denominations have spread their worship places to all the ten regions of the Republic of Cameroon. Every where one goes now in Cameroon, one will find members of these churches. In fact, these churches have successfully penetrated into the Muslim dominated northern region. The numerous Catholic and Protestant parishes, congregations, dioceses, presbyteries, fields, ecclesiastical provinces, schools and health institutions that resulted from this cross country evangelism stand above ethnic and regional cleavages.

In addition, unity among men, women and youths of mainstream churches is promoted through fellowship groups. Protestant denominations brought men together under the Christian Men Fellowship while the Catholics did so under the Christian Family Movement. Concerning women, Catholics created Catholic Women Association (CWA) while Protestants formed Christian Women Fellowship. As noted by Funteh, youths from all the churches formed the Christian Youth Fellowship. ${ }^{55}$ The national character of these associations, apart from dismantling ethnic differences among Christians, enable these churches to accompany the government in promoting national integration in a country marred by numerous disparities. As a matter of fact, these fellowship groups interact with each other at cross denominational level. For example, they all participate in the World Day of Prayers, an ecumenical activity. Mirabel Azangeh Tandafor, National President of CWA, stressed that the CWA invites sister groups of other churches to its activities. ${ }^{56}$ It is important to note that, with the aid of these fellowships, mainline churches enhanced national cohesion by championing the cause of aculturalisation of the church in Cameroon. They are integrating some aspects of the local culture in an effort to accommodate Christians from diverse ethnic backgrounds. In spite the integrative character of churches' evangelical activities, most of the congregations resulting from the expansion of mainline denominations from Anglophone Cameroon to Francophone Cameroon and vice-versa are respectively dominated by Anglophones and Francophones who have resettled in such places.

\section{CONCLuSiON}

This paper has examined the contributions of the actions and policies of mainline churches to the forging of a cohesive national community in Cameroon from a large number of ethnic groups and confessions as well as from the dual colonial heritages. The manner in which mainstream churches knowingly and unknowingly involved themselves in the process of national integration in Cameroon thus bear witness, in an exemplary fashion, to the role they have played in the gradual construction of

52.Dah, "The Vision and Challenges", p. 39-42.

53. Ejedepang-Koge, S. N., "Expansion of the Presbyterian Church in Cameroon in to Francophone Cameroon", in Dah J. N., (ed.), Presbyterian Church in Cameroon: 50 Years of Selfhood, Limbe, Presprint, 2007, pp. 74.

54. For an insightful discussion of the planting of the $\mathrm{CBC}$ in Francophone Cameroon, read Funteh, "IntraCameroon Baptist Convention Conflicts", pp. 111-113.

55. See Funteh, "A Historical Survey of the Strategy for Church Expansion", p. 58.

56. See M. Azangeh, "Taking a panoramic view at the National CWA", in L'Effort Camerounais, No. 503, April 2012. 
national accommodation and common citizenship in Cameroon since the reunification of the country. The paper concludes that the cross-cutting affiliations of these churches alongside their structural transformations and ecumenical and evangelical activities, in addition to forging Christian unity, promote national unity in Cameroon. Indeed, the churches' structures, ecumenical bodies and evangelical initiatives, in spite some impediments, transcend the multi-ethnic differences and the dual colonial heritages, coinciding with the boundaries of the national state. As projected in the foregoing discussion, churches did not only foster national unity, but were equally affected by it.

Although mainstream churches have aided the process of national cohesion in Cameroon since reunification, there exist church-related constraints to national integration. For instance, the ongoing intra and inter-confessional conflicts can be harmful to Christian unity and national integration. The persistent Northwest/Southwest dichotomy in the PCC undeniably remains an impediment to the national integration project. ${ }^{57}$ Besides, the neglect of bilingualism during church sermons especially in metropolitan towns like Yaoundé, Douala, Bamenda and Bafoussam remains incessantly injurious to national cohesion in Cameroon. Furthermore, the multiplication of Pentecostal churches has aggravated denominational competition and at the same time created a greater need for Christian unity. ${ }^{58}$ As a matter of fact, when competition develops among churches, their potential to contribute to national cohesion is undermined. And given that ethnic and colonial disparities (the persistent Anglophone problem, ethnic-oriented multi-party politics, and the presence of rival ethnic and regional associations) are still visible in Cameroon, it is necessary for Christian denominations to explore new ways and means of further promoting Christian unity and national integration.

\section{REFERENCES}

Akoko, R. B., "New Pentecostalism in the Wake of Economic Crisis in Cameroon", in Nordic Journal of African Studies, 11 (3), 2002, pp. 359-376.

Amougou, A. G., «Le Conseil des Eglises Protestantes de Yaoundé (CEPY): De 1954 a 2004. Essai D’Analyse Historique », Mémoire de Master en Histoire, Université de Yaoundé 1, 2012, 126 p.

Azangeh, M., "Taking a panoramic view at the National CWA", in L'Effort Camerounais, No. 503, April 2012.

Cameroon, http://www.state.gov/documents/organization/171604.pdf. Accessed on 10 May 2012.

Barot, M., Le Mouvement Oecuménique, Paris, Presses Universitaire de France, 1967.

Birmele, A., (ed.), Local Ecumenism: How Church Unity is Seen and Practiced by Local Congregations, Strasbourg, Institute for Ecumenical Research, 1984.

Cavert, S. M., On the Road to Christian Unity: An Appraisal of the Ecumenical Movement, New York, Harpers and Brothers Publishers, 1961.

Chimi, D. H., «Les Organes de Promotion de l'unité des Protestants au Cameroun 1941-2005», Mémoire de Maitrise en Histoire, Université de Yaoundé 1, 2007.

Dah, J. N., "The Vision and Challenges of an Autonomous Church", in Dah J. N., (ed.), Presbyterian Church in Cameroon: 50 Years of Selfhood, Limbe, Presprint, 2007, pp. 15-55.

--------, Presbyterian Church in Cameroon: 50 Years of Selfhood, Limbe, Presprint, 2007.

Dudley, B. J., "Military Government and National Integration in Nigeria" in Smock, David and Bentsi-Enchill, K., eds., The Search for National Integration in Africa, New York, The Free Press, 1972, pp. 117-139.

Ejedepang-Koge, S. N., "Expansion of the Presbyterian Church in Cameroon in to Francophone Cameroon", in Dah J. N., (ed.), Presbyterian Church in Cameroon: 50 Years of Selfhood, Limbe, Presprint, 2007, pp. 74-91.

Etuge, O., "Church Union in Cameroon", Bachelor Dissertation in Theology, Theological College Nyasoso, 1977, $70 \mathrm{p}$.

Fanso, V. G., Cameroon History for Secondary Schools and Colleges, Vol. 2, The Colonial and Post Colonial Periods, London, Macmillan, 1989.

57.For an insightful discussion of this divide, read M. Lang, "The Northwest/Southwest Dichotomy in the Presbyterian Church in Cameroon 1957-2009: A Historical Survey", Forthcoming.

58. For more information on this, see R. B. Akoko, "New Pentecostalism in the Wake of Economic Crisis in Cameroon", in Nordic Journal of African Studies, 11 (3), 2002, pp. 359-376; A. A. Samah, "Pentecostal Churches in Cameroon: The Case of Four Urban Centres ; Yaounde, Douala, Bamenda and Limbe, 19492005", Maitrise Dissertation in History, University of Yaounde 1, 2006. 
Fonlon, B., "The Language Problem in Cameroon: An Historical Perspective" in Smock, David and Bentsi-Enchill, K., eds., The Search for National Integration in Africa, New York, The Free Press, 1972, pp. 189-206.

Funteh, M. B., "A Historical Survey of the Strategy for Church Expansion in Cameroon: The Case of the Mainstream Denominations" in Kaliao, Volume 1, No. 2, December 2009, pp. 49-68.

---------, "Intra-Cameroon Baptist Convention Conflicts 1954-2002: A Historical Investigation", $\mathrm{Ph} . \mathrm{D}$. Thesis in History, University of Yaounde I, 2008, 489 p.

Kah, H. K. and Nkwi, W. G., "Colonial Boundaries and Disintegration: A Study of the Boki 'Nation' of the Cross River Region of Cameroon and Nigeria", in Daniel Awa, Albert-Pascal Temgoua et al., eds. Boundaries and History in Africa: Issues in Conventional Boundaries and Ideological Frontiers, Bamenda, Maryland Publishers, 2011, pp. 44-53.

Lang, M. K., "Constitutional Crisis within the Presbyterian Church in Cameroon 1957-2009", PanTikar Journal of History, Vol. 1, No. 1, March 2013.

---------, “The Menchum-Boyo Presbytery-Goppingen Deanery Partnership 1968-2008: A Historical Investigation" Ph.D Thesis in History, University of Yaounde 1, 2012, 546 p.

LeVine, V. T., "Political Integration and the United Republic of Cameroon" in Smock, David and Bentsi-Enchill, K., eds., The Search for National Integration in Africa, New York, The Free Press, 1972, pp. 270-285.

Monga, Y., « «Au village! » , Cahiers d'études africaines [Online], 160|2000, Accessed on 5 May 2012. URL : http://etudesafricaines.revues.org/46

Mveng, E., Histoire des Eglises Chrétiennes au Cameroun : Les Origines, Yaoundé, Imprimerie Saint Paul, 1990.

Mujom., I. L., "The Origin and Evolution of the East Mungo North Presbytery of the Presbyterian Church in Cameroon, 1964-2004", Master Dissertation in History, University of Yaounde 1, 2007, $120 \mathrm{p}$.

Ndi, A., Mill Hill Missionaries in Southern West Cameroon 1922-1972: Prime Partners in Nation Building, Nairobi, Paulines Publications Africa, 2005.

Ngoh, V. G., History of Cameroon Since 1800, Limbe, Presbook, 1996.

Ngwa, H. A., "Ecumenism in Cameroon: A Survey of Some Ecumenical Developments from the 1960s to 1991", Bachelor Dissertation in Theology, Presbyterian Theological College Kumba, 1991, $46 \mathrm{p}$.

Nyansako-ni-Nku, Journey in Faith: The Story of the Presbyterian Church in Cameroon, 1957-1982, Buea, Bumakor, 1982.

Samah, A. A., "Pentecostal Churches in Cameroon: The Case of Four Urban Centres ; Yaounde, Douala, Bamenda and Limbe, 1949-2005", Maitrise Dissertation in History, University of Yaounde 1, 2006.

Sanosi,„E. F., "The Catholic Church - architect of national integration in Cameroon" L'Effort Camerounais, No. 503, June 2010.

Southall, A., "The Current State of National Integration in Uganda" in Smock, David and BentsiEnchill, K., eds., The Search for National Integration in Africa, New York, The Free Press, 1972, pp. 307-333.

Werner, K., The History of the Presbyterian Church in West Cameroon, Victoria, Presbook, 1969.

Willard, J., The Cameron Federation. Political Integration in a Fragmentary Society, Princeton, Princeton University Press, 1970.

\section{AUTHOR'S BIOGRAPHY}

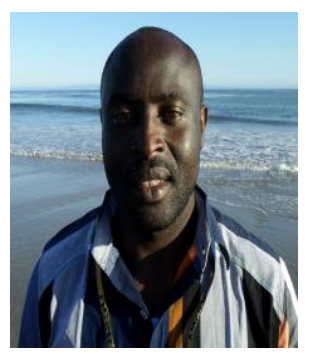

Michael Kpughe Lang, is holder of a PhD degree in Religious History and hails from Cameroon. He is a Senior Lecturer/Researcher at the Department of History, Higher Teacher Training College of the University of Bamenda, Cameroon. He was a Fulbright Scholar at the University of Santa Barbara, California USA in 2013 and has published on areas of gender, politics and religion in national and international journals. 